\title{
Impact of Selected Macro-Economic Variables on the Export Performance of Bangladesh
}

\author{
Farhana Rahman \\ Lecturer, Department of Business Administration in Finance and Banking, Bangladesh University of \\ Professionals, Dhaka, Bangladesh
}

\begin{abstract}
This paper investigates the short run and long run dynamics between export performance of Bangladesh and selected macro-economic variables using various econometrics tools. The variables considered are Interest rate, Inflation rate, Broad money (M2), and Exchange rate and Quantum index of industrial production. Monthly data has been analyzed over the period spanning July 2011 to June 2016. According to Johansen multivariate co-integration tests the export of Bangladesh and the selected five macroeconomic variables are co-integrated, this gives a clear indication of long-run associations. No short-run dynamics is found through error correction model which is again strengthened by Variance Decomposition (VDC) tests. The $V D C$ test established that, a significant proportion of the variability in the export performance was mainly due to its own innovations while only a minimal proportion was explained by the chosen variables. The findings of existent long run relationship and no short-run dynamics can help astute policy makers in making efficient, appropriate and effective decisions regarding Export performance and policy.
\end{abstract}

Keywords: Macro-economic variables, Cointegration, ECM, Granger Causality, Variance decomposition

\section{Introduction}

Bangladesh is considered to be one of the fastest growing economies registering 7.11\% GDP growth rate in fiscal year 2016 (Bangladesh Bureau of Statistics, 2016). At present Bangladesh is a net importer meaning value of import is greater than value of export but it is the second largest apparel exported currently just after China. This shows how much important Bangladesh is to the outside world. In FY 2016 the value of export from Bangladesh stood at $\$ 34.24$ billion which was $\$ 31.21$ billion in FY 2015 (Export Promotion Bureau, 2016). In FY 2016 export earnings showed some revival sign with a growth rate of $9.7 \%$ which was only 3.4\% in FY 2015. The reason of sluggish growth in FY 2014-15 was due to the shattered image of Bangladeshi apparel manufacturers to the outside world after the Rana Plaza collapse in 2013. From FY 2007 to FY 2016 the CAGR of export revenue was exceptionally well to 12.2\%. The export earnings of Bangladesh are mostly concentrated on apparel exports which constitute approximately more than $80 \%$ of total export revenue in a given year. Apparel in FY 2016 stood at $\$ 28.09$ billion which was approximately $82 \%$ of total export from Bangladesh (Export Promotion Bureau, 2016). It was in FY 2011 when export revenue growth was 41.5\%. Almost all of the growth came along with buoyant export growth during that fiscal year. The reason behind that is, during that period the global financial crisis shrank the purchasing power of most people of the foreign countries and Bangladesh was one of the cheapest sources of merchandise products and riding on the capability of providing goods at a cheaper rate the country established itself as one of major apparel exporter from fiscal year 2011 and currently holds the second position after China. Currently the export sector is only 17.3\% of GDP which is very less compared to other developing as well as developed countries (World Bank, 2015). Total export is over reliant on apparel export and any major difficulties in apparel export will affect the overall export adversely. Although current export revenue receipt as percentage of GDP is very less but the major export earner is one of the major employers of the people of the country. The CAGR of 12.2\% from FY 2007 to FY 2016 also indicates the accelerating growth potential of export revenue for the country.

Keeping in mind all these, it is important to identify what factors affect the export performance in the short run and long run. The independent variables selected for the study are the ones which are expected to have direct affect to the export performance to some extent. The study aims to help policymakers develop strategy based on the relationship of the variables, if any, with export.

\section{Literature Review}

The study aims to reveal if there is any relationship among the selected independent variables and export performance in the long run and short run. This sections aims to focus on the literature review. Robertson (1938) justifies the importance of export policy and argues that export facilitates economic growth, so considerable efforts should be given towards the enhancement of export production. The studies done by Largely (2008), Oyejide (2006) Ballasa (2008), Michaly (2007), Ram (2005), Onitiri (2003), Ojo (1973), and Tyler (1981) have thrown light on the contributions and importance of export as the engine of economic growth 
in developing countries. However not much studies have been done on the impact of macro-economic variables i.e. interest rate, inflation rate, exchange rate, production and money supply on the export performance of a particular nation.

Countries that are heavy borrowers, export growth is very crucial for them to service debts. Apart from that, countries suffering from high inflation and sagging consumption demand should rely on export growth for economic growth (Malmgreen,2008). Tyler (1981) also argues in favor of export oriented diversification policies and put forward the achievement of countries like Hong Kong, Singapore, Korea, and Taiwan for export led growth strategy.

McConnell and Brue (2008) define inflation as "rising level of prices". The rate of change in prices is inflation, and the price level is the accumulation of previous inflations (Dornbusch et al., 2012). Aslanov E., Gasimov T. \& Isayeva have found a significant impact of inflation on the export of Azerbaijan and Georgia in their studies. Ball, et.all (2004) concluded that Inflation rate has an impact on international trade. When inflation rate is high in a country, the price of good and services offered by that country increases as well. Increased prices make the goods and services offered by that country less competitive in international market. According to the study conducted by Gylfason (1997) on the association between export and some of its macroeconomic determinants including inflation covering 160 countries using cross sectional data, it is concluded that high inflation results in reduced export.

Gross Domestic Product (G.D.P) is basically the summary of all the final goods and services produced in a given time inside the national economy. Analysis found that GDP growth is related with export while studying the relation between GDP and exports (Aslanov E., et.al. 2010). According to the study conducted by Erygit (1981) a lasting correlation is found between foreign direct investments and GDP, export volume and GDP and Foreign direct Investment and export volume through residual based test. However due to unavailability of data, industrial production index is taken as a proxy for national production in this particular study.

An exchange rate specifies the rate at which the currency of one country can be exchanged for another for facilitating transactions among countries (Madura, 2013). The macroeconomic situations of a country will certainly be influenced by the real exchange rate, especially net exports or the balance trade, so relationship between exchange rate and net exports or balance of trade is evident (Mankiw, 2003). In case of floating exchange rates system, a change in export or import will occur if the value of the currency depreciates or appreciates. If there is depreciation of exchange rate, the value of local currency in terms of foreign currencies will decrease resulting in the increase in the export volume which means the export will automatically increase if the value of exchange rate rose, (Sukirno, 2004).

Monetary aggregates are M1 (narrow money), M2 and M3 (broad money). M1 includes currency in circulation and demand deposits held at the central bank and deposit money banks, M2 includes M1 plus time deposits held at deposit money banks. Increase in money supply can theoretically increase the export performance through chain reaction generating through interest rate, FDI and exchange rate.

\section{Objective of the study}

- To identify the short run and long run equilibrium relationship between dependent variable i.e. Export and independent variables under this study.

- To determine whether the selected macroeconomic variables can predict the future export performance of Bangladesh.

- $\quad$ To know the ways by which the amount of sensitivity between variables can be identified.

\subsection{Data Description}

\section{Data Description and Model Specification}

In the study we have used data from July 2011 to June 2016. For a robust estimation of the model, monthly frequency has been chosen to maximize the number of observations. The data on Export (LNEXPORT), and Interest rate (LNIR) and Inflation rate (LNIF), Money supply (LNM2), Exchange rate of BDT against USD (LNEX) have been collected from Bangladesh Bank which is the Central Bank of Bangladesh. The data on Industrial production (LNQIIP) index has been obtained from the monthly publication of Bangladesh Bureau of Statistics. All the variables are expressed in natural logarithm form to normalize the data for analysis purpose. Weighted average interest rates on lending of schedule banks' are taken as a proxy for interest rate while quantum index of industrial production is taken as a proxy for production.

\subsection{Model Specification}

\subsubsection{Unit root test}

In analyzing time series data, examining if the data set is trending or not is very essential. If the data set is trending, the data is non-stationary. A problem of non-stationary data might generate the problem of spurious 
regression with high $\mathrm{R}^{2}$ even if the variables are totally unrelated and $\mathrm{t}$ ratios will not be following $\mathrm{t}$ distributions. So we need to check if the data has unit root or not. The Augmented Dickey-Fuller (ADF) test which is an extension of Dickey -Fuller test is taken to check Stationarity.

The null and alternative hypotheses are as follows:

Unit root [Variable is not stationary]

No unit root [Variable is stationary]

If the null hypothesis is rejected, it will be meaning that the series is stationary.

\subsubsection{Johansen Co-integration test and Error Correction Mechanism}

Integration test checks the presence of long run associations among the variables to be analyzed. If data series are integrated at same order Johansen Cointegration test can be applied. Maximal Eigenvalue and Trace statistics both are used for checking number of co-integrating vectors. Existence of cointegration will conclude a long-term equilibrium relationship between variables. If no cointegration is found, VECM is not required anymore and directly Granger causality tests can be applied to establish causal links between variables.

After studying cointegration if any cointegration relationship can be found, then modeling of the short run affiliation between the variables can be represented by a Vector Error Correction Model. Information about the short-run dynamics is incorporated in VECM and tests conducted within VECM framework are recommended to be more powerful than their counterparts within a VAR model. There may be disequilibrium in the short-run

\subsubsection{Granger causality}

Statistical hypothesis which helps in identifying whether one time series is beneficial in predicting another time series is known as granger causality test. Whether previous values of a variable help to forecast changes in other variable or not is determined through this test (Granger, 1988). In addition, it also puts light on the fact that if variable $\mathrm{Y}$ is Granger caused by variable $\mathrm{X}$ or not when $\mathrm{X}$ helps in forecasting the value of variable Y (Sarbapriya, 2012).

Granger Causality test examines the association between individual explanatory variables and the dependent variable and specifies the direction of relationship like whether the relationship is unidirectional, bidirectional or there remains no relation. Cointegration test tells about long run association among variables while VECM depicts short run dynamics and association. But the direction of relationship can be determined by granger causality test. Variables need to be made stationary before running granger causality test.

\subsubsection{Variance Decomposition}

The standard Granger causality analysis interprets the relationship among variables within the sample period only on the other hand variance decomposition analysis can be used to deduce relationships beyond the particular sample period. Actually, Variance Decomposition specifies the percentage of the forecast error variance in one variable that is attributable to errors in forecasting itself and each of the other variables (Tarik, 2001).

\subsection{Unit root test}

\section{Empirical Results}

The unit-root test is conducted on Export time series and all the chosen macroeconomic variables to identify whether the time series is stationary or not. The ADF test is run at level and first difference with intercept and trend and intercept as summarized below-

Table 1: Augmented Dicky Fuller unit root test results with Export and other macroeconomic variables

\begin{tabular}{|c|c|c|c|}
\hline \multirow{2}{*}{ Variable } & \multicolumn{3}{|c|}{ ADF Test Statistics } \\
\cline { 2 - 4 } & level & $1^{\text {st }}$ difference & $\begin{array}{c}\text { Test critical } \\
\text { Value at 5\% }\end{array}$ \\
\hline LNEXPORT & -1.426126 & $-8.532708^{*}$ & -2.91 \\
\hline LNIF & -1.581567 & $-4.047070^{*}$ & -2.91 \\
\hline LNQIIP & 0.870300 & $-6.016094^{*}$ & -2.92 \\
\hline LNER & -2.431862 & $-6.160299^{*}$ & -2.91 \\
\hline LM2 & -2.499293 & $-9.991318^{*}$ & -3.49 \\
\hline LNIR & -2.461106 & $-5.906501^{*}$ & -3.49 \\
\hline *denotes rejection of null hypothesis \\
\hline
\end{tabular}


In the Table 1, test statistics and test critical value are given. If test statistics is lower than test critical value, we will accept the null hypothesis ADF test is run on the variables LNIR, LNM2 with intercept and trend while constant model is assumed to test ADF on LNIF, LNQIIP, LNEXPORT, and LNER.

By looking at the results from table 1, it appears that the test statistics for all the included variables in our research are lower than the test critical value at $5 \%$. So we cannot reject the null hypothesis which means the variables have unit root which makes the variables non-stationary at level. This suggests that the first difference of those variables need to be taken to check if the variables are stationary at first difference or not. After taking the first difference, we see the variables have become stationary as test statistics value is higher that test critical value in this case.

\subsection{Johansen Co-integration test}

As the variables are integrated at order one, Cointegration method can be used to estimate the long run association between variables. Both Trace statistics and Maximum Eigenvalue statistics is used in order to identify the numbers of co-intergraing vectors. The results of Trace statistics and Maximum Eigenvalue are shown in Table 3 and Table 4 respectively.

Table 2: Unrestricted Cointegration Rank Test (TRACE)

\begin{tabular}{|c|c|c|c|c|}
\hline $\begin{array}{c}\text { Hypothesized } \\
\text { No. of CE(s) }\end{array}$ & Eigenvalue & $\begin{array}{c}\text { Trace } \\
\text { Statistic }\end{array}$ & $\begin{array}{c}\mathbf{0 . 0 5} \\
\text { Critical Value }\end{array}$ & Prob.** \\
\hline None $*$ & 0.605268 & 166.6707 & 95.75366 & 0.0000 \\
\hline At most 1* & 0.546882 & 113.6864 & 69.81889 & 0.0000 \\
\hline At most 2* & 0.401386 & 68.56496 & 47.85613 & 0.0002 \\
\hline At most 3* & 0.364564 & 39.31607 & 29.79707 & 0.0030 \\
\hline At most 4 & 0.210234 & 13.46981 & 15.49471 & 0.0987 \\
\hline At most 5 & 0.000294 & 0.016740 & 3.841466 & 0.8969 \\
\hline Trace test indicates 4 cointegrating eqn(s) at the 0.05 level \\
\hline * denotes rejection of the hypothesis at the 0.05 level \\
\hline
\end{tabular}

Table 3: Unrestricted Cointegration Rank Test (Maximum Eigenvalue)

\begin{tabular}{|c|c|c|c|c|}
\hline $\begin{array}{c}\text { Hypothesized } \\
\text { No. of CE(s) }\end{array}$ & Eigenvalue & $\begin{array}{c}\text { Max-Eigen } \\
\text { Statistic }\end{array}$ & $\begin{array}{c}\mathbf{0 . 0 5} \\
\text { Critical Value }\end{array}$ & Prob.** \\
\hline None * & 0.605268 & 52.98432 & 40.07757 & 0.0011 \\
\hline At most 1* & 0.546882 & 45.12140 & 33.87687 & 0.0015 \\
\hline At most 2* & 0.401386 & 29.24889 & 27.58434 & 0.0303 \\
\hline At most 3* & 0.364564 & 25.84626 & 21.13162 & 0.0101 \\
\hline At most 4 & 0.210234 & 13.45307 & 14.26460 & 0.0669 \\
\hline At most 5 & 0.000294 & 0.016740 & 3.841466 & 0.8969 \\
\hline Max-eigenvalue test indicates 4 cointegrating eqn(s) at the 0.05 level \\
\hline *denotes rejection of the hypothesis at the 0.05 level \\
\hline
\end{tabular}

The Trace Test and maximum eigenvalue test shown in Table 2 and Table 3 indicates the existence of 4 cointegrating equation at the $5 \%$ significance level. This cointegrating equation means that one linear combination exists between the variables that force these indices to have a relationship over the entire sample time period The normalized cointegrating coefficients were estimated as reported in Table 4.

Table 4: Normalized Cointegrating Coefficients

\begin{tabular}{|c|c|c|c|c|c|}
\hline LNEXPORT & LNIF & LNIR & LNER & LNM2 & LNQIIP \\
\hline 1.000000 & 0.233308 & -1.367703 & 0.839184 & -0.242422 & -1.011416 \\
\hline Standard error & $(0.08929)$ & $(0.26681)$ & $(0.40021)$ & $(0.07987)$ & $(0.13894)$ \\
\hline
\end{tabular}

As the existence of four cointegrating equation have been found, the presence of stable equilibrium relationship is identified. The results are normalized on the Export. To enable proper interpretation, the signs are reversed due to the normalization process,.

\section{LNEXPORT = -0.233 LNIF + 1.37 LNIR - 0.839 LNER + 0.242 LNM2 + 1.01 LNQIIP}

So, this clearly shows that in the long run there is a negative impact on export from inflation. On the other hand, in the long run interest rate, money supply and industrial production index has a positive impact on export. Again, exchange rate seems to have a negative influence on export according to the cointegration 
equation found by Johansen co-integration test statistics. The result is indicating that in Bangladesh a percent increase in exchange rate and inflation contributes to $.233 \%$ and $.839 \%$ decrease in export respectively in the long run. On the contrary, interest rate and industrial production index and money supply shows positive relationship where $1 \%$ increases in interest rate and industrial production and money supply index will increase the export by $1.37 \%, 1.01 \%$ and $.242 \%$.

\subsection{Vector Error Correction Model}

As the presence of the long-term relationship in the system is indicated by multivariate co-integration test, it is required to estimate them in a Vector Error Correction Model (VEC). System equation for VECM is calculated and the estimation of equation is given below-

Table 5: estimation of system equation of VECM

\begin{tabular}{|c|c|c|c|c|c|}
\hline \multicolumn{2}{|c|}{} & Coefficient & Std. Error & t-Statistic & Prob. \\
\hline $\begin{array}{c}\text { Coefficient of co- } \\
\text { integrated model }\end{array}$ & $\mathbf{C}(\mathbf{1})$ & $\mathbf{- 0 . 2 1 4 2 6 0}$ & $\mathbf{0 . 2 4 6 5 3 8}$ & $\mathbf{- 0 . 8 6 9 0 7 4}$ & $\mathbf{0 . 0 2 9 6}$ \\
\hline $\mathrm{D}(\mathrm{LNEXPORT(-1))}$ & $\mathrm{C}(2)$ & -0.567146 & 0.240044 & -2.362675 & 0.0227 \\
\hline $\mathrm{D}(\mathrm{LNEXPORT(-2))}$ & $\mathrm{C}(3)$ & -0.244344 & 0.194315 & -1.257465 & 0.2154 \\
\hline $\mathrm{D}(\mathrm{LNIF}(-1))$ & $\mathrm{C}(4)$ & 0.049852 & 0.201142 & 0.247843 & 0.8054 \\
\hline $\mathrm{D}(\mathrm{LNIF}(-2))$ & $\mathrm{C}(5)$ & 0.055739 & 0.198383 & 0.280966 & 0.7801 \\
\hline $\mathrm{D}(\mathrm{LNIR}(-1))$ & $\mathrm{C}(6)$ & 1.373090 & 1.889327 & 0.726761 & 0.4713 \\
\hline $\mathrm{D}(\mathrm{LNIR}(-2))$ & $\mathrm{C}(7)$ & -1.549804 & 1.725577 & -0.898137 & 0.3741 \\
\hline $\mathrm{D}(\mathrm{LNER}(-1))$ & $\mathrm{C}(8)$ & -0.508021 & 1.081290 & -0.469828 & 0.6409 \\
\hline $\mathrm{D}(\mathrm{LNER}(-2))$ & $\mathrm{C}(9)$ & -0.075728 & 1.024123 & -0.073944 & 0.9414 \\
\hline $\mathrm{D}(\mathrm{LNM}(-1))$ & $\mathrm{C}(10)$ & -1.960407 & 1.357483 & -1.444148 & 0.1559 \\
\hline $\mathrm{D}(\mathrm{LNM}(-2))$ & $\mathrm{C}(11)$ & 0.535988 & 1.358225 & 0.394624 & 0.6951 \\
\hline $\mathrm{D}(\mathrm{LNQIIP}(-1))$ & $\mathrm{C}(12)$ & -0.200364 & 0.207744 & -0.964475 & 0.3402 \\
\hline $\mathrm{D}(\mathrm{LNQIIP}(-2))$ & $\mathrm{C}(13)$ & 0.091751 & 0.170514 & 0.538084 & 0.5933 \\
\hline $\mathrm{C}$ & $\mathrm{C}(14)$ & 0.026177 & 0.027295 & 0.959037 & 0.3429 \\
\hline
\end{tabular}

Here, $\mathrm{C}(1)=$ is the coefficient of co-integrated model which refers to the speed to adjustment towards equilibrium Here the co-efficient C (1) is significant and negative as well. So it means there long run causality running from independent variables to export.

Other coefficients are short run coefficients, not long run. From the system equation we can see that C2 and $\mathrm{C} 3$ are short run coefficients for RMG export at lag 1 and 2. In the same way, C4 and C5 are coefficients for inflation; $\mathrm{C} 5$ and $\mathrm{C} 6$ are for; $\mathrm{C} 7$ and $\mathrm{C} 8$ are for exchange rate; $\mathrm{C} 9$ and $\mathrm{C} 10$ for money supply; $\mathrm{C} 12$ and $\mathrm{C} 13$ for interest rate. Now, we will check short run coefficient can jointly influence dependent variable or not. To check this we will use Wald statistics. The results of Wald statistics is shown in the following table-

Table 6: Result of Wald Statistics

\begin{tabular}{|l|l|l|}
\hline Variable (co-efficient) & Null Hypothesis & P value (chi square) \\
\hline LNIF (C4, C5) & LNIF does not influence RMG export in the short run & 0.9263 \\
\hline LNIR (C6, C7) & LNIR does not influence RMG export in the short run & 0.6295 \\
\hline LNER (C8,C9) & LNER does not influence RMG export in the short run & 0.8894 \\
\hline LNM2 (C10, C11) & LNM2 does not influence RMG export in the short run & 0.2511 \\
\hline LNQIIP (C12,C13) & LNQIIP does not influence RMG export in the short run & 0.3172 \\
\hline *Indicates reject null hypothesis at 5\% significance level & \\
\hline
\end{tabular}

So there is no short run causality running from independent variable to dependent variable is shown by our VECM findings. The result (Table 6) also shows that in the short run none of the variable shows a significant relationship with Bangladesh export through the results of Wald test statistics.

\subsection{Granger Causality}

To analyze the possible endogenous relationship between export and selected macroeconomic variables, Granger causality test is performed to help examine whether macroeconomic development is encouraging export or there is no relation at all. The first differences of the variables are taken and then The Granger-causality test was applied in the study because granger causality test has to be done on stationary data only. The results are shown in Table-7. The results imply that, there is no bidirectional Granger causality existing between export and the selected macroeconomic determinants. Again, no causality is found in either direction between the export and the macroeconomic variables. So the export performance of Bangladesh to be 'caused' by the neither macroeconomic variables, nor does it have a significant influence on them.

DOI: $10.9790 / 5933-0802032127 \quad$ www.iosrjournals.org $\quad 25 \mid$ Page


Table 7: Pairwise Granger Causality Test for Export and Macroeconomic Variables

\begin{tabular}{|c|c|c|}
\hline Null hypothesis & P value & Relationship \\
\hline DLNIF does not Granger Cause DLNEXPORT & 0.9886 & No relationship \\
DLNEXPORT does not Granger Cause DLNIF & 0.2530 & No relationship \\
\hline DLNIR does not granger cause DLNEXPORT & 0.4637 & \\
\hline DLNEXPORT does not granger cause DLNIR & 0.0678 & No relationship \\
\hline DLNEX does not granger cause DLNEXPORT DLNEXPORT does not & 0.9348 & \\
\hline granger cause DLNEX & 0.0435 & No relationship \\
\hline DLNM2 does not granger cause DLNEXPORT & 0.3093 & 0.0546 \\
\hline DLNQIIP does not granger cause DLNEXPORT & 0.5530 & No relationship \\
\hline DLNEXPORT does not granger cause DLNQIIP & 0.3376 & \\
\hline
\end{tabular}

\subsection{Variance Decomposition}

In order to supplement the Granger causality results the variance decomposition analysis was employed so that out of sample impact can be reinvestigated. The result indicates what extent of own shock of export is explained by its own movements and chosen macroeconomic variables over the forecast horizon of 10 months. The results in table 8 shows that the amount of variance of the export explained by own goes down when the time horizon increased up to 10 months. 94 per cent of the variance of export is explained by own at horizon 2 . On the other hand, 91 per cent of export variance is explained by itself when the horizon is increased up to 10 . It points to the fact that at longer horizons, the variance of export may be triggered by variance of other macroeconomic factors.

Table: 8: Variance Decomposition of LNEXPORT

\begin{tabular}{|l|l|l|l|l|l|l|l|}
\hline $\begin{array}{c}\text { Perio } \\
\mathrm{d}\end{array}$ & S.E. & LNEXPORT & LNIF & LNIR & LNER & LNM2 & LNQIIP \\
\hline 1 & 0.074955 & 100.0000 & 0.000000 & 0.000000 & 0.000000 & 0.000000 & 0.000000 \\
\hline 2 & 0.078744 & 94.07408 & 0.004449 & 1.882846 & 0.831265 & 3.194179 & 0.013183 \\
\hline 3 & 0.090898 & 91.54726 & 0.194046 & 1.423069 & 0.625483 & 4.371381 & 1.838765 \\
\hline 4 & 0.097017 & 91.16299 & 0.422819 & 1.575205 & 0.581221 & 4.371148 & 1.886613 \\
\hline 5 & 0.104080 & 91.04385 & 0.606291 & 1.574326 & 0.565639 & 3.898130 & 2.311765 \\
\hline 6 & 0.109746 & 91.20434 & 0.849706 & 1.610914 & 0.513041 & 3.534621 & 2.287378 \\
\hline 7 & 0.115840 & 91.48805 & 0.985173 & 1.596844 & 0.493073 & 3.174239 & 2.262623 \\
\hline 8 & 0.121220 & 91.51850 & 1.126627 & 1.627742 & 0.512495 & 2.910857 & 2.303775 \\
\hline 9 & 0.126788 & 91.61531 & 1.217171 & 1.630823 & 0.517752 & 2.660793 & 2.358156 \\
\hline 10 & 0.131764 & 91.60481 & 1.309933 & 1.659179 & 0.515703 & 2.465229 & 2.445141 \\
\hline
\end{tabular}

So it can be seen form Variance decomposition that there is very weak long run relationship among the variables in the study. It is also established through VECM that, there is no short run causal relationship between Export and the chosen macroeconomic variables. These results indicate that using macroeconomic variables, the Export in Bangladesh cannot be predicted thoroughly.

\section{Conclusion and Policy Implication}

In this paper, attempts have been made towards examination of the impact of macroeconomic variables on Bangladesh export applying different econometric techniques of Johansen co-integration, Granger- Causality, Error Correction Model (ECM) and Variance Decomposition (VDC). The macroeconomic variables such as Inflation rate, Interest rate, Exchange rate of BDT against USD, Broad money supply (M2), and Industrial Production (IP) measured by quantum index of industrial production have been taken as explanatory variables to investigate the impact on export as dependent variable between the periods from July 2011 to June 2016.

By applying ADF, we find all the six variables have unit root in the level and are made stationary when the first difference is taken. Johansen co-integration test indicates the existence of cointegrating vector that established existence of long-run relationship between Bangladesh export and the chosen macroeconomic variables. No short run casualty is found between the dependent and explanatory variables. The Granger Causality test implies that export performance of Bangladesh does not appear to be 'caused' by the macroeconomic variables. It even does it have a significant influence on the selected macro-economic variables except uni-directional causality running from export to exchange rate.

A major and significant proportion of the variability in the export was explained by its own innovations while only a minority (insignificant) was explained by chosen macro-economic variables is revealed by VDC analyses. This implies that there are many other macroeconomic factors which affect the fluctuation in export performance. Overall, it is established that there exists no short run causal relationship between export and macro-economic variables. However, there exists weak long run relationship. These results from the study indicates that export in Bangladesh cannot be predicted only using the selected macroeconomic variables. 
Astute policy makers can be benefited by the result of this study in their decision making and can concentrate on other conditions and variables that impact the export performance of Bangladesh.

\section{Reference}

[1]. Tomar, Rohit Singh, and Dr. Deepika Singh Tomar. "Selected Macro- Economic Variables and Its Impact on Chinese and Indian Exports." IOSR Journal of Business and Management 16.3 (2014): 01-08.

[2]. Ahmed, Haydory Akbar and Md. Gazi Salah Uddin. "Export, Imports, Remittance And Growth In Bangladesh: An Empirical Analysis". Trade and Development Review 2.2 (2009): 9-92.

[3]. Muktadir-Al-Mukit, Dewan and A. Z. M. Shafiullah. "Export, Import and Inflation: A Study On Bangladesh". ResearchGate (2014)

[4]. Engle, Robert F. and C. W. J. Granger. "Co-Integration And Error Correction: Representation, Estimation, And Testing". Econometrica 55.2 (1987): 251

[5]. Rwenyagila, Geofrey A. "DETERMINANTS OF EXPORT PERFORMANCE IN TANZANIA". (2013)

[6]. Muktadir-al-Mukit, Dewan. "Effects Of Interest Rate And Exchange Rate On Volatility Of Market Index At Dhaka Stock Exchange". Journal of Business and Technology (Dhaka) 7.2 (2013)

[7]. Maggiora, Daniel Della and Robert Skerman. "Johansen Cointegration Analysis of American and European Stock Market Indices: An Empirical Study". Master's thesis in Finance, Lund University.

[8]. Ilegbinosa, Anthony Imoisi, Peter Uzomba, and Richard Somiari. "The Impact of Macroeconomic Variables On Non-Oil Exports Performance In Nigeria, 1986-2010". Journal of Economics and Sustainable Development 3.5 (2012)

[9]. Octavia, Evania Rahma. "Analysis of Effect Macro Variable on International Trade of Indonesia". Business and Economic Research (2016)

[10]. Roslan, Faten Nadirah. "A Study On The Dynamic Relationship Between Inflation, Foreign Direct Investment, International Trade And Economic Growth In Malaysia". SSRN Electronic Journal.

[11]. Johansen, Soren. "Times Series: Cointegration". SSRN Electronic Journal.

[12]. Kumari, Deepika and Neena Malhotra. "Export And Economic Growth In Select South Asian Countries: Causality Analysis Based On Granger Test \& VECM". Arthshastra : Indian Journal of Economics \& Research 4.4 (2015): 21.

[13]. Cheung, Yin-Wong and Rajeswari Sengupta. "Impact Of Exchange Rate Movements On Exports: An Analysis Of Indian NonFinancial Sector Firms". SSRN Electronic Journal.

[14]. Puhan, Tatjana-Xenia. "Time-Varying Asset Valuations And Macroeconomic Uncertainty: The Role Of Inflation, Monetary Policy And Macroeconomic Conditions". SSRN Electronic Journal.

[15]. Abdel-Latif, Abla M. "The Nonprice Determinants Of Export Success Or Failure: The Egyptian Ready-Made Garment Industry, 1975-1989". World Development 21.10 (1993): 1677-1684

[16]. Love, J. "The Determinants of Export Performance Of Developing Countries". Journal of Economic Studies 9.3 (1982): $55-60$. 